\title{
Conceptual Review: Interpersonal Attraction dalam Padangan Sosial, Perkembangan dan Kognitif
}

\author{
Siti Mahmudah ${ }^{1}$ \\ ${ }^{1}$ Universitas Airlangga, Indonesia
}

\author{
A R T I C L E I N F O \\ Article history: \\ Received 26 July 2021 \\ Accepted 03 November \\ 2021 \\ Available online 01 \\ December 2021 \\ Kata Kunci: \\ Interpersonal Attraction; \\ Pandangan Sosial; Kognitif \\ Keywords: \\ Interpersonal Attraction; \\ Social Perspective \\ Cognitive
}

\begin{abstract}
A B S T R A K
Individu bertemu untuk saling berinteraksi, adanya interaksi menjadi dasar ketertarikan pada seseorang. Interpersonal attraction biasanya didasarkan pada teori sosial, namun bagaimana para ahli dalam aliran-aliran lain memandang ketertarikan dalam aliran lain, seperti pandangan perkembangan dan kognitif memandang interpersonal attraction. Penelitian ini bertujuan untuk mengetahui konsep interpersonal attraction dari reviu jurnal-jurnal penelitian sebelumnya dengan beberapa perspektif teori. Pengumpulan data dilakukan dengan reviu dari 12 literatur dengan rentang tahun 2010 hingga 2020 dan jurnal diperoleh dari bebrapa situs web resmi Google Scholar, Research Gate, Jstor, dan Social Science. Hasil penelitian menunjukkan konsep interpesonal attraction dapat diartikan dengan arah positif maupun arah negatif, pengaruh kehadiran emosi individu yang positif dapat memberikan penilaian positif terhadap orang lain, begitupun sebaliknya. Selain daripada kehadiran emosi individu,
\end{abstract} terdapat hal-hal lain seperti, atraksi, perbandingan sosial, kenyamanan, kecocokan kepribadian dan juga exposure. Perilaku kita lebih menyukai orang lain dalam interpersonal attraction dapat dipengaruhi oleh lingkungan dan intensitas dari interaksi.

\section{A B S T R A C T}

Individu was meeting to interact with each other. The interaction becomes based on attraction to others. Interpersonal attraction is usually based on social theory, but experts in other streams view the interpersonal attraction, such as developmental and cognitive perspectives. This study aims to determine the concept of interpersonal attraction from reviews of the previous research article. Data collection was carried out by reviewing 12 literature ranges from 2010 to 2020 and articles obtained from Google Scholar, Research Gate, Jstor, and Social Science websites. The results showed that the concept of interpersonal attraction could be interpreted in a positive direction or a negative direction. The influence of the presence of positive individual emotions can provide a positive assessment of others. Apart from individual emotions, there are other things such as attractions, social comparisons, comfort, personality compatibility, and exposure.

\footnotetext{
* Corresponding author.

E-mail addresses: siti.mahmudah-2020@psikologi.unair.ac.id
} 



\section{Pendahuluan}

Kedekatan fisik yang terjadi dengan orang lain dapat menurunkan atau meningkatkan kemungkinan individu-individu yang bertemu untuk saling berinteraksi, hal ini dapat menjadi dasar ketertarikan seseorang. Secara umum ketertarikan seseorang didasarkan pada teori sosial, namun bagaimana para ahli dalam aliran-aliran lain memandang ketertarikan dalam perspektif lain, seperti perspektif perkembangan dan kognitif dalam memandang interpersonal attraction. Sehingga seseorang menjadi saling mengenal dengan adanya pengalaman kontak satu sama lain, respon awal terhadap penampilan, seringkali muncul akibat dari reaksi emosional, kemiripan satu sama lain juga hal penting, begitupun dengan interaksi yang menarik juga merupakan hal yang penting. Menggambarkan bagaimana dua orang menjadi saling kenal, akibat dari pertemuan yang tidak disengaja, seperti disekolah, ditempat kerja, ataupun dilingkungan tempat tinggal mereka. Hal-hal lain seperti keadaan afektif (emosi) juga menjadi penting, reaksi emosional kita terhadap orang lain yang kita temui kemungkinan telah ditentukan dari bagaimana kita mengamati karakteristik lawan kontak kita. Dalam ranah psikologi ketertarikan dengan orang lain disebut dengan interpersonal attraction.

Interpersonal attraction kembali pada suatu sikap diri kepada orang lain, dapat menjadi suka maupun tidak suka, memang pada kenyataannya ada individu yang disukai dan ada yang tidak disukai oleh orang lain. Atas dasar apakah kita menyukai atau tidak menyukai orang lain akan penulis bahas dalam reviu artikel ini. Penelitian-penelitian sebelumnya dengan tema interpersonal attracttion akan digunakan untuk mengindentifikasikan faktor-faktor yang mempengaruhi interpersonal attraction dalam reviu ini. Sehingga dapat mempermudah dalam membaca faktor-faktor yang mempengaruhi. Banyak psikolog sosial yang meyakini bahwa evaluasi (penilaian) positif berasal dari perasaan yang positif dan evaluasi (penilaian) negatif berasal dari perasaan negatif, yang artinya interpersonal attraction dapat ditentukan oleh emosi individu. Namun juga perlu dipahami bahwa tingkah laku intepersonal lebih kompleks daripada hanya sekedar rasa emosi positif dan emosi negatif. Kehadiran emosi tertentu memiliki efek terhadap evaluasi kita terhadap orang lain. Prinsip dasarnya bahwa pengaruh positif mengarah pada penilaian positif dan pengaruh negatif mengarah pada penilaian negatif, artinya emosi dapat mempengaruhi penilaian kita baik secara langsung maupun tidak langsung.

Sebagai konsep, interpersonal attraction dapat dilihat dari beberapa perspektif, dalam masa ini, dengan kemajuan teknologi dan komunikasi, interpesonal attraction dapat dilihat dalam beberapa pandangan, ada perspektif secara virtual dan perspektif didunia nyata. Sebelumnya interaksi antar manusia sebelum kemajuan teknologi dan internet, interaksi terjadi dengan kontak langsung dan timbal balik, setelah kemajuan internet interaksi terjadi tanpa adanya kontak langsung, manusia dapat berinteraksi dengan ke pasifan, sehingga terjadinya perubahan interpersonal attraction diantara individu. Hubungan interpersonal seseorang didasarakan pada rasa kesukaan diantara dua orang, daya tarik dapat menjadi salah satu penyebab terjadinya suatu hubungan. Motif interaksi dapat dicapai dengan adanya ketertarikan diantara individu yang berinteraksi. Byrne (1971) menyatakan bahwa teori atraksi, ketika individu lebih mirip kepada orang lain, semakin besar kemungkinan dia untuk tertarik. Byrne \& Griffitt, (1973) mengatakan bahwa interpersonal attraction adalah sikap seseorang terhadap orang lain, ketertarikan diantara orang-orang yang mengarah pada persahabatan dan romantic relationship. Interaksi yang sehat adalah sesuatu yang wajib. Sehingga menjadi sesuatu hal yang penting dalam suatu hubungan dengan interpersonal attraction. Melihat interpersonal attraction melalui beberapa perspektif teori.

Interpersonal attraction menjadi konsep yang penting dalam teori dan penelitian yang berkaitan dengan psikologi sosial (Liu, Yin, \& Huang, 2013). Hasil analisis mengungkapkan perbedaan yang signifikan dalam hubungan interpersonal dalam kehidupan nyata dengan teman, hubungan interpersonal dalam kehidupan nyata dengan orang tua, dan hubungan interpersonal virtual dengan teman. Interaksi facebook dapat memfasilitasi interpersonal attraction dengan teman-teman mereka, namun penggunaan facebook yang berlebihan dapat melemahkan hubungan dengan orang tua mereka dalam dunia nyata (Walster, Berscheid, \& Walster, 1978) dalam (Bekiari \& Spyropoulou, 2016). Interpersonal attraction mengacu pada kecenderungan estimasi dan perasaan positif pada orang lain, sebagai salah satu penentu bagi perkembangan dan 
kelanjutan hubungan dalam lingkungan sosial (Ünal-Çolak \& Kobak, 2011). Daya tarik interpersonal terdiri dari tiga dimensi, sosial, tugas, dan daya tarik fisik (McCroskey \& McCain, 1974) dalam (Bekiari \& Petanidis, 2016; Bekiari \& Spyropoulou, 2016).

Menurut (Montoya \& Horton, 2004) evaluasi kognitif sebagai prediktor interpersonal attraction secara signifikan. Komposisi kognitif dihasilkan sebelum adanya penilaian interpersonal attraction, sedangkan model integrasi informasi tidak seperti itu (Montoya \& Horton, 2004). Konseptualisasi proses kognitif dan pengalaman ketertarikan dikonseptualisasikan melalui model tripartit sikap (Katz \& Stotland, 1959; Rosenberg, Hovland, McGuire, Abelson, \& Brehm, 1960) dalam (Montoya \& Horton, 2004) bahwa sikap, evaluasi objek tertentu, mencakup tiga komponen; afektif (respon emosional terhadap objek sikap), kognitif (pemikiran dan keyakinan akan objek sikap), dan perilaku (kecenderungan untuk bertindak dengan cara terntu terhadap objek sikap). Yang artinya, interpersonal attraction seseorang berdasarkan pandangan kognitif mengikuti prinsip yang ditentukan oleh evaluasi kognitif orang lain. McGinley \& Reiner (1979) berdasarkan penelitiannya, dikatakan ada hubungan yang positif diantara kesamaan sikap dan hubungan interpersonal beradasarkan aspek kognitif dan non kognitif.

Montoya \& Horton (2014) dalam (Nikoleizig, Nestler, Krause, Moore, \& Biesanz, 2019) mendefinisikan interpersonal attraction sebagai evaluasi positif maupun negatif dari individu kepada individu lain. Para peneliti telah menunjukkan bahwa interpersonal attraction berkorelasi positif dengan kesamaan kepribadian (Goldman, Rosenzweig, \& Lutter, 1980). Individu cenderung menginginkan pasangan romantis yang mirip dengan diri mereka sendiri baik dalam hal keramahan, kesadaran, ekstrovesi, stabilitas, emosional, dan keterbukaan terhadap pengalaman (Botwin, Buss, \& Shackelford, 1997) dan gaya keterikatan (Klohnen \& Luo, 2003) dalam (Islam, Saha, Naz, Shila, \& Shithee, 2019). Kommers \& Isaias (2011) mengembangkan kuesioner berdasarkan teori interpersonal attraction (McCroskey \& McCain, 1974; Walster et al., 1978) yang terdiri dari daya tarik sosial dan daya tarik fisik.

Interpersonal attraction memiliki arti yang positif, seseorang cenderung menyukai mereka yang memiliki kesamaan nilai dan efek negatif yang ditujukan kepada satu orang, yang berarti sikap orang untuk menilai orang lain itu baik atau tidak (Sharma \& Gautam, 2013). Byrne (1971) menyatakan bahwa teori atraksi, ketika individu lebih mirip kepada orang lain, semakin besar kemungkinan dia untuk tertarik. Selain itu, Liu et al. (2013) menyatakan bahwa interaksi remaja dengan teman, orang tua, dan guru dapat berbeda sehingga terjadi hubungan interpersonal yang berbeda dengan objek yang berbeda. Chou \& Peng (2007) mengemukakan mayoritas remaja taiwan tidak memberitahu orang tua mereka tentang kencan online mereka dan mempercayai hubungan yang dibangun secara online. Suler (2004) mengungkapkan bahwa orang akan terbuka pikirannya saat berhubungan dengan orang lain di internet. Orang lebih bersedia mengungkapkan diri di internet daripada dikehidupan nyata (Katelyn Y. A. McKenna, Amie S. Green, \& Marci E. J. Gleason, 2002). Penggunaan facebook secara wajar, memiliki efek positif pada hubungan interpersonal remaja (Liu et al., 2013), karena berbagai jenis interaksi dalam kehidupan nyata dan virtual dapat dikembangkan secara terpisah (Liu et al., 2013).

Artikel ini ditulis dengan harapan dapat memberikan pemahaman yang lebih baik tentang interpersonal attraction secara keseluruhan berdasarkan konsep-konsep yang telah didapatkan penulis, dengan berdasar pada pertanyaan-pertanyaan yang telah disrumuskan, yaitu (1) interpersonal attraction sebagai sebuah konsep, (2) faktor-faktor yang mempengaruhi interpersonal attraction, (3) perspektif teori dalam memahami interpersonal attraction.

\section{Metode}

Artikel ini didasarkan pada reviu dari 12 literatur dengan rentang tahun 2010 sampai 2020 dan jurnal diperoleh dari berbagai sumber. Datanya dikumpulkan dengan meninjau situs web resmi Google Scholar, Research Gate, Jstor, dan Social Science. Setiap artikel dipilih berdasarkan pertanyaan-pertanyaan yang disusun oleh penulis sebagai langkah pertama memahami interpersonal attraction sebagai sebuah konsep. Spesifik pertanyaan meliputi: (1) interpersonal attraction sebagai sebuah konsep; (2) faktor-faktor yang mempengaruhi interpersonal attraction; (3) perspektif teori dalam memahami interpersonal attraction. Hal-hal 
yang terkait pertanyaan-pertanyaan diatas dikumpulkan untuk bacaan lebih lanjut. Langkah selanjutnya adalah melakukan identifikasi tema utama dalam literatur ini. Data yang dikumpulkan dari setiap artikel kemudian diurutkan menurut pertanyaan-pertanyaan diatas, kemudian dianalisis sesuai dengan pertanyaanya.

\section{Hasil dan Pembahasan \\ Interpersonal attraction sebagai sebuah konsep}

Kehadiran emosi tertentu memiliki efek terhadap evaluasi kita terhadap orang lain. Prinsip dasarnya bahwa pengaruh positif mengarah pada penilaian positif dan pengaruh negatif mengarah pada penilaian negatif, artinya emosi dapat mempengaruhi penilaian kita baik secara langsung mapuan tidak langsung. Para peneliti telah menunjukkan bahwa interpersonal attraction berkorelasi positif dengan kesamaan kepribadian (Goldman et al., 1980). Individu cenderung menginginkan pasangan romantis yang mirip dengan diri mereka sendiri baik dalam hal keramahan, kesadaran, ekstrovesi, stabilitas, emosional, dan keterbukaan terhadap pengalaman (Botwin et al., 1997) , dan gaya keterikatan (Klohnen \& Luo, 2003) dalam (Islam et al., 2019). Dalam (Baruh \& Cemalcllar, 2018) Pengungkapan diri (self disclosure) dapat meningkatkan daya tarik interpersonal dengan menandakan niat positif dari pengungkap (Collins \& Miller, 1994). Lott \& Lott (1965) dalam studinya menunjukkan bahwa interpersonal attraction secara positif mempengaruhi prestasi akademik siswa, dimana siswa cenderung belajar lebih cepat ketika mereka bekerja dengan orang mereka cintai. Interpersonal attraction antara siswa dan guru dikembangkan, mereka akan memiliki kesempatan yang lebih baik untuk membangun komunikasi positif dikelas, jadi komunikasi yang efektif ini dapat mendukung efektivitas proses balajar mengajar (Gumelar \& Gilipanda, 2019). Hasil penelitian sebelumnya berdasarkan konteks, metodologi dan instrumen penelitian dapat dilihat pada Tabel 1.

Byrne (1971) mengungkapkan bahwa teori atraksi, ketika individu lebih mirip kepada orang lain, semakin besar kemungkinan dia untuk tertarik. Interpersonal attraction memiliki arti yang positif, seseorang cenderung menyukai mereka yang memiliki kesamaan nilai dan efek negatif yang ditujukan kepada satu orang, yang berarti sikap orang untuk menilai orang lain itu baik atau tidak (Sharma \& Gautam, 2013). Perbandingan sosial juga akan memeberikan pengaruh interaksi interpersonal positif ataupun negatif. Hasilnya tergantung pada banyak faktor, seperti karakteristik individu, situasi dan arah perbandingan sosial (Ding, Liu, \& Qing, 2018).

Zajonc menyebutkan secara umum kita berespon dengan paling tidak sedikit rasa tidak nyaman ketika kita bertemu dengan siapapun yang tidak dikenal atau tidak familiar. Wajah yang dikenal atau familiar tidak hanya dievaluasi positif, namun juga menyebabkan aktivasi otak yang menghasilkan respon emosi positif. Jika dari awal emosi yang terkembang adalah sangat negatif maka repeated exposure (kedekatan) tidak akan berarti apapun, bahkan dapat memperburuk emosi negatif yang dirasakan.

Tabel 1.

Review penelitian sebelumnya berdasarkan konteks, metodologi dan instrumen penelitian.

\begin{tabular}{|c|c|c|c|c|}
\hline No & Title/ Researcher & Contexts & Methodology & Intruments \\
\hline 1 & $\begin{array}{l}\text { exploration of verbal aggressiveness } \\
\text { and interpersonal attraction through } \\
\text { social network analysis: using } \\
\text { university physical education class as an } \\
\text { illustration/ alexandra bekiari, spyreta } \\
\text { spyropoulou }\end{array}$ & greece & quantitative & $\begin{array}{l}\text { verbal aggresiveness } \\
\text { scale, interpersonal } \\
\text { attraction scale }\end{array}$ \\
\hline 2 & $\begin{array}{lrr}\text { exploring } & \text { teacher's } & \text { verbal } \\
\text { aggressiveness through interpersonal } \\
\text { atraction and student's intrinsic } \\
\text { motivation/ alexandra bekiari, } \\
\text { dimitrios petanidis }\end{array}$ & gree & qual & $\begin{array}{l}\text { questionnaires verbal } \\
\text { aggressiveness, } \\
\text { attractiveness and } \\
\text { intrinsic motivation }\end{array}$ \\
\hline 3 & $\begin{array}{l}\text { adolescent's interpersonal relationships } \\
\text { with friends, parents, and teachers } \\
\text { when using facebook for interaction/ }\end{array}$ & taiwan & survey method & $\begin{array}{l}\text { interpersonal } \\
\text { relationship } \\
\text { (RIR) }\end{array}$ \\
\hline
\end{tabular}




\begin{tabular}{|c|c|c|c|c|}
\hline & $\begin{array}{l}\text { shih-hsiung liu, mei-chun yin, tsung- } \\
\text { hsien huang }\end{array}$ & & & \\
\hline 4 & $\begin{array}{l}\text { prediction of group performance: the } \\
\text { interplay of individual performance, } \\
\text { interpersonal attraction, and } \\
\text { interpersonal behaviour }\end{array}$ & germany & $\begin{array}{l}\text { quantitative, } \\
\text { group, } \\
\text { obervational. }\end{array}$ & $\begin{array}{l}\text { questionnare } \\
\text { interpersonal } \\
\text { attraction, the moon } \\
\text { landing task }\end{array}$ \\
\hline 5 & $\begin{array}{l}\text { effect of gender, economic status, } \\
\text { religion, partner's economic status on } \\
\text { interpersonal attraction among the } \\
\text { university students/ md hasibul islam, } \\
\text { dr asoke kumar saha, hamida naz, shirin } \\
\text { shila, ummee habiba shithee }\end{array}$ & indian & quantitative & $\begin{array}{l}\text { interpersonal scale of } \\
\text { McCroskey and McCain } \\
(1974)\end{array}$ \\
\hline 6 & $\begin{array}{l}\text { when more is more? The impact of } \\
\text { breadth and depth of } \\
\text { informationdisclosure on attraibutional } \\
\text { confidence about and interpersonal } \\
\text { attraction to a social network site } \\
\text { profile owner/ lemi baruh, zeynep } \\
\text { cemalcilar }\end{array}$ & U.S & experiment & $\begin{array}{l}\text { interpersonal } \\
\text { attraction scale }\end{array}$ \\
\hline 7 & $\begin{array}{l}\text { exploring the relationship between } \\
\text { impression management and } \\
\text { interpersonal attraction in social } \\
\text { networking site/ hueiju yu, pei-shan } \\
\text { wei, hsi-peng lu, jen-chuen Tzou }\end{array}$ & $\begin{array}{l}\text { taipei, } \\
\text { taiwan, } \\
\text { republic of } \\
\text { china }\end{array}$ & & questionnaire \\
\hline 8 & $\begin{array}{l}\text { teacher's voice and student } \\
\text { interpersonal attractiveness/ gumgum } \\
\text { gumelar }\end{array}$ & $\begin{array}{l}\text { jakarta, } \\
\text { indonesia }\end{array}$ & $\begin{array}{l}\text { pre- } \\
\text { experiment } \\
\text { design }\end{array}$ & $\begin{array}{l}\text { the scale consists of } \\
\text { statements based on } \\
\text { the theory } \\
\text { interpersonal of } \\
\text { inaterest. (Baron \& } \\
\text { Byrne, 2003) }\end{array}$ \\
\hline 9 & $\begin{array}{l}\text { modeling and measurement of } \\
\text { interpersonal attraction } \\
\text { coordination in charged social space- } \\
\text { time/ alan s. haas }\end{array}$ & usa & $\begin{array}{l}\text { experimental } \\
\text { method }\end{array}$ & simulting \\
\hline 10 & $\begin{array}{l}\text { personality, subjective well-being and } \\
\text { interpersonal attraction in adolescents/ } \\
\text { anita sharma, jyotsana gautam }\end{array}$ & indian & $\begin{array}{l}\text { quantitative, } \\
\text { correlation }\end{array}$ & $\begin{array}{l}\text { using } 16 \quad \mathrm{PF}, \quad \text { The } \\
\text { Subjective Well-Being } \\
\text { Inventory } \\
\text { Interpersonal } \\
\text { attraction Scale } \\
\end{array}$ \\
\hline 11 & $\begin{array}{l}\text { the interpersonal impact of social } \\
\text { comparison/ ming ding, yaozhang liu, } \\
\text { qinghua li }\end{array}$ & china & $\begin{array}{l}\text { summary } \\
\text { analysis }\end{array}$ & \\
\hline 12 & $\begin{array}{l}\text { from first sight to friendship: A } \\
\text { longitudinal social relations analysis } \\
\text { and change in interpersonal attraction/ } \\
\text { mitja D back, stefan C schmukle, Boris } \\
\text { egloff }\end{array}$ & jerman & experimental & scale \\
\hline
\end{tabular}

\section{Faktor penentu interpersonal attraction}

Lott \& Lott (1965) dalam studinya menunjukkan bahwa interpersonal attraction secara positif mempengaruhi prestasi akademik siswa, dimana siswa cenderung belajar lebih cepat ketika mereka bekerja dengan orang mereka cintai. Meningkatkan daya tarik dan hubungan antara guru dan siswa dapat dilakukan dengan, guru memiliki kemampuan menyampaikan materi terutama menggunakan suara sebagai gaya mengajar, meninggikan atau menjaga suara dapat meningkatkan fokus dan hasil belajar siswa (Gumelar \& Gilipanda, 2019). (Haas, 2015) pencocokan kepribadian akan terjadi dengan menciptakan interpersonal attraction yang dioptimalkan dan koordinasi yang sesuai. 
Sharma \& Gautam (2013) mengungkapkan bahwa perilaku kita lebih menyukai orang lain dalam interpersonal attraction dipengaruhi oleh, lingkungan dan interaksi yang sering, kesan pertama bertemu bukan sebagai prasangka, adanya kesamaan perilaku, mood positive, kemenarikan fisik, respon positif dari lawan interaksi, dan keadaan emosi. Dalam interpersonal attraction ada pengaruh secara langsung ataupun tidak langsung mengenai emosi. Secara umum, (Ben-Porath, 2002) bahwa kita cenderung menyukai orang yang baik kepada kita dan membuat kita merasa baik daripada kepada orang lain yang tidak baik kepada kita. Pengaruh emosi pada suka dan tidak suka datang dari prinsip-prinsip conditioning, ketika kita berada dalam suasana hati yang positif kita manilai orang lain (lawan kontak) dengan cara yang positif, dan begitupun sebaliknya apabila kita berada dalam suasana hati yang negatif (Berry \& Hansen, 1996). Dan banyak juga faktor-faktor lain, seperti kepercayaan, bias budaya, stereotip, dll.

Faktor eksternal yang mempengaruhi interpersonal attraction, proximity dua orang menganal satu sama lain apabila telah terjadi kontak lingkungan fisik secara berulang. Ketertarikan terhadap orang lain, dapat terjadi karena seringnya terjadi kontak (zajonc, 1965). Daya tarik fisik, terkadang anda mungkin merasa tertarik terhadap orang lain yang tidak anda kenal pada pandangan pertama. (Diener, Wolsic\& Fujita, 1995) bahwa daya tarik biasanya dikaitkan dengan popularitas, harga diri, dan keterampilan intepersonal yang baik. Fisik seseorang juga mempengaruhi reaksi emosioanl dan daya tarik yang berbeda (Ryckman, Robbins, Kaczor, \& Gold, 1989), selain itu berbagai karakteristik fisik yang terlihat seperti kecacatan fisik, penyakit mental, persepsi usia, jenggot, dan kacamata, dll. Juga mempengaruhi interpersonal attraction.

Berbagai penelitian dilakukan menunjukkan korelasi yang positif, yang memiliki arti dua arah yaitu saling menyukai pada pasangan mengarah pada pengembangan kesamaan atau kesamaan diantara mereka yang menyebabkan mereka saling menyukai (Hunt, 1935). Kita mencari seseorang dengan kepercayaan dan sikap yang sama dengan kita. NewComb (1956) menunjukkan bahwa kesamaanlah yang merupakan prediktor yang baik untuk rasa suka diantara dua individu.

\section{Perspektif teori dalam memahami interpersonal attraction}

Dampak interpersonal dari perbandingan sosial terbagi menjadi dua aspek. Diantaranya adalah struktur perbandingan sosial dan karakteristik pribadi (Ding et al., 2018). Dalam struktur perbandingan sosial, didalamnya jumlah orang yang berpartisipasi dalam sosial meningkat, seseorang akan menurunkan motivasi bersaingnya. Selanjutnya adalah karakteristik pribadi, perbandingan sosial antara sesama jenis dapat menghasilkan lebih banyak perilaku interpersonal negatif, untuk mengurangi interpersonal negatif dapat dilakukan penilaian diri sendiri. (Pellegrini, 2007) Menunjukkan wanita secara tidak langsung akan menyerang mereka karena rasa iri terhadapa kecantikan wanita lain dan hal ini dapat merusak hubungan.

Dalam sisi perkembangan intepersonal attraction biasanya digambarkan sebagai proses yang lambat menuju keintiman dan kedekatan (Berscheid \& Regan, 2005; Hays, 1988; Levinger, 1994). Sebagai proses yang mengandalkan komunikasi yang berulang dan intim. Intepersonal attraction pada pandangan pertama didasarkanpada isyarat fisik atau isyarat nonverbal yang mudah diamati (Berscheid \& Reis, 1998; Sabatelli \& Rubin, 1986). Berdasarkan hasil penelitian (Back, Schumkle, \& Egloff, 2010) perkembangan interpersonal attraction menunjukkan bahwa daya tarik interpersonal attraction itu stabil dan dapat berubah berdasarkan lamanya waktu.

Menurut teori kognitif menekankan proses berpikir sebagai dasar menentukan tingkah laku. Tingkah laku sosial dipandang sebagai suatu hasil dari proses akal. (Montoya \& Horton, 2004) evaluasi kognitif sebagai prediktor interpersonal attraction secara signifikan. (McGinley \& Reiner, 1979) Dikatakan ada hubungan yang positif diantara kesamaan sikap dan hubungan interpersonal beradasarkan aspek kognitif dan non kognitif. Berdasar teori penguatan dasar ketertarikan datang dari bagaimana ketertarikan datang untuk pertama kalinya, bahwa individu ditarik oleh hadiah dan ditolak oleh hukuman. Menurut teori interaksionis, keterterikan interpersonal dihubungkan pada suatu situasi sosial, dan menitik beratkan bahwa interpersonal attraction adalah suatu konsep. 
Sebagi konsep, interpersonal attraction dipengaruhi emosi, emosi positif mengarah pada penilaian positif dan emosi negatif mengarah pada penilaian negatif, artinya emosi dapat mempengaruhi penilaian kita baik secara langsung mapuan tidak langsung. Interpersonal attraction memiliki arti yang positif, seseorang cenderung menyukai mereka yang memiliki kesamaan nilai dan efek negatif yang ditujukan kepada satu orang, yang berarti sikap orang untuk menilai orang lain itu baik atau tidak (Sharma \& Gautam, 2013). (D. E. Byrne, 1971) Bahwa teori atraksi, ketika individu lebih mirip kepada orang lain, semakin besar kemungkinan dia untuk tertarik. Dan menurut Zajonc menyebutkan secara umum kita berespon dengan paling tidak sedikit rasa tidak nyaman ketika kita bertemu dengan siapapun yang tidak dikenal atau tidak familiar. Wajah yang dikenal atau familiar tidak hanya dievaluasi positif, namun juga menyebabkan aktivasi otak yang menghasilkan respon emosi positif.

Lott \& Lott (1965) dalam studinya menunjukkan bahwa interpersonal attraction secara positif mempengaruhi prestasi akademik siswa, dimana siswa cenderung belajar lebih cepat ketika mereka bekerja dengan orang mereka cintai. Interpersonal attraction antara siswa dan guru dikembangkan, mereka akan memiliki kesempatan yang lebih baik untuk membangun komunikasi positif dikelas, jadi komunikasi yang efektif ini dapat mendukung efektivitas proses balajar mengajar (Gumelar \& Gilipanda, 2019).

Perilaku kita lebih menyukai orang lain dalam interpersonal attraction dipengaruhi oleh, lingkungan dan interaksi yang sering, kesan pertama bertemu bukan sebagai prasangka, adanya kesamaan perilaku, mood positive, kemenarikan fisik, respon positif dari lawan interaksi, dan keadaan emosi (Sharma \& Gautam, 2013).

Beberapa perspektif teori, Menurut teori kognitif menekankan proses berpikir sebagai dasar menentukan tingkah laku. Tingkah laku sosial dipandang sebagai suatu hasil dari proses akal. Dengan menggunakan evaluasi kognitif seseorang melakukan interpersonal attraction, karena evaluasi kognitif seseorang mempengaruhi kesamaan sikap pada ketertarikan interpersonal. Berdasar teori penguatan dasar ketertarikan datang dari bagaimana ketertarikan datang untuk pertama kalinya, bahwa individu ditarik oleh hadiah dan ditolak oleh hukuman. Menurut teori interaksionis, keterterikan interpersonal dihubungkan pada suatu situasi sosial, dan menitik beratkan bahwa interpersonal attraction adalah suatu konsep.

\section{Simpulan dan Saran}

Konsep interpesonal attraction dapat diartikan dengan arah positif maupun arah negatif, pengaruh kehadiran emosi individu yang positif dapat memberikan penilaian positif terhadap orang lain, sedangkan kehadiran emosi negatif juga dapat memberikan penilaian negatif terhadap kehadiran orang lain. Selain daripada kehadiran emosi individu, terdapat hal-hal lain seperti, atraksi, perbandingan sosial, kenyamanan, kecocokan kepribadian dan juga exposure. Perilaku kita lebih menyukai orang lain dalam interpersonal attraction dapat dipengaruhi oleh lingkungan dan intensitas dari interaksi, kesan pertama bertemu bukan sebagai prasangkan, kesamaan perilaku, respon positif dari lawan interaksi, kemenarikan fisik, mood positive, dan keadaan emosi. Interpesonal attraction dalam pandangan teori sosial terbagi menjadi dua, aspek perbandingan sosial, dan aspek karakteristik pribadi. Dalam perbandingan sosial, jumlah individu yang bergabung meningkat dapat menurunkan motivasi bersaing seseorang. Dan karakteristik pribadi, menyatakan perbandingan sosial antar sesama jenis dapat menghasilkan lebih banyak perilaku interpersonal negatif. Dalam pandangan teori perkembangan interpersonal attraction digambarkan sebagai proses yang lambat menuju kedekatan karena mengandalkan komunikasi yang berulang dan intim. Daya tarik interpersonal attraction dapat stabil dan sewaktu-waktu dapat berubah berdasar lamanya waktu. Teori kognitif memandang interpersonal attraction menekankan proses berfikir sebagai dasar yang menentukan tingkahlaku, dengan mendasarkan pada teori ketertarikan bahwa individu ditarik oleh hadiah dan ditolak oleh hukuman.

Temuan penelitian pada tinjauan literatur ini diharapkan memberikan kontribusi pada peneliti-peneliti lain yang akan menggunakan interpersonal attraction sebagai variabel, dalam tinjauan tiga perspektif yaitu, sosial, perkembangan dan kognitif. Dan saran bagi peneliti selanjutnya untuk melakukan tinjauan dengan perspektif lain, seperti perspektif behavioral atau perspektif psikologi kepribadian dalam interpersonal attraction. 


\section{Daftar Rujukan}

Back, M. D., Schumkle, T. C., \& Egloff, B. (2010). from first sight to friendship: A Longitudinal social relations analysis of stability and change in interpersonal attraction. 891.

Baruh, L., \& Cemalcllar, Z. (2018). When more is more? The impact of breadth and depth of information disclosure on attributional confidence about and interpersonal attraction to a social network site profile owner. Cyberpsychology, 12(1). https://doi.org/10.5817/CP2018$1-1$

Bekiari, A., \& Petanidis, D. (2016). Exploring Teachers' Verbal Aggressiveness through Interpersonal Attraction and Students' Intrinsic Motivation. Open Journal of Social Sciences, 04(12), 72-85. https://doi.org/10.4236/jss.2016.412007

Bekiari, A., \& Spyropoulou, S. (2016). Exploration of Verbal Aggressiveness and Interpersonal Attraction through Social Network Analysis: Using University Physical Education Class as an Illustration. Open Journal of Social Sciences, 04(06), 145-155. https://doi.org/10.4236/jss.2016.46016

Berry, D. S., \& Hansen, J. S. (1996). Positive affect, negative affect, and social interaction. Journal of Personality and Social Psychology, 71(4), 796-809. https://doi.org/10.1037/00223514.71.4.796

Berscheid, E., \& Reis, H. T. (1998). Attraction and close relationships. In The handbook of social psychology, Vols. 1-2, 4th ed. (pp. 193-281). New York, NY, US: McGraw-Hill.

Botwin, M. D., Buss, D. M., \& Shackelford, T. K. (1997). Personality and mate preferences: five factors in mate selection and marital satisfaction. Journal of Personality, 65(1), 107-136. https://doi.org/10.1111/j.1467-6494.1997.tb00531.x

Byrne, D. E. (1971). The attraction paradigm (Vol. 462). Academic press.

Byrne, D., \& Griffitt, W. (1973). Interpersonal Attraction. Annual Review of Psychology, 24(1), $317-$ 336. https://doi.org/10.1146/annurev.ps.24.020173.001533

Chou, C., \& Peng, H. (2007). Net-friends: Adolescents' attitudes and experiences vs. teachers' concerns. Computers in Human Behavior, 23(5), 2394-2413. https://doi.org/https://doi.org/10.1016/j.chb.2006.03.015

Collins, N. L., \& Miller, L. C. (1994). Self-disclosure and liking: A meta-analytic review. Psychological Bulletin, Vol. 116, pp. 457-475. https://doi.org/10.1037/0033-2909.116.3.457

Ding, M., Liu, Y., \& Qing, H. (2018). The Interpersonal Impact of Social Comparison. Psychology, 09(04), 797-808. https://doi.org/10.4236/psych.2018.94051

Goldman, J. A., Rosenzweig, C. M., \& Lutter, A. D. (1980). Effect of similarity of ego identity status on interpersonal attraction. Journal of Youth and Adolescence, 9(2), 153-162. https://doi.org/10.1007/BF02087933

Gumelar, G., \& Gilipanda, E. K. A. (2019). Teacher's Voice And Student Interpersonal Attractiveness. (November). https://doi.org/10.4108/eai.20-1-2018.2281907

Haas, A. S. (2015). Modeling and measurement of interpersonal attraction and coordination in charged social Space-Time. NeuroQuantology, 13(1), 1-9. https://doi.org/10.14704/nq.2015.13.1.801

Islam, H., Saha, A. K., Naz, H., Shila, S., \& Shithee, U. H. (2019). Effect of Gender , Economic status , Religion, Partner's Economic Status on Interpersonal Attraction among the University Students. The International Journal of Indian Psychology, 7(1). https://doi.org/10.25215/0701.039

Katelyn Y. A. McKenna, Amie S. Green, \& Marci E. J. Gleason. (2002). Relationship formation on the Internet: what's the big attraction. Journal of Social Issues, 58(1), 9-31.

Katz, D., \& Stotland, E. (1959). A preliminary statement to a theory of attitude structure and change. Psychology: A Study of a Science, 3(423-475).

Klohnen, E. C., \& Luo, S. (2003). Interpersonal attraction and personality: What is attractive--self similarity, ideal similarity, complementarity or attachment security? Journal of Personality and Social Psychology, 85(4), 709.

Kommers, P., \& Isaias, P. (2011). Exploring The Relationship Between Impression Management And Interpersonal Attraction In Social Networking Site. IADIS International Conferences Web Based Communities 2011, 213 Collaborative Technologies 2011 and Internet Applications and 
Research 2011, (February 2018).

Liu, S.-H., Yin, M.-C., \& Huang, T.-H. (2013). Adolescents' Interpersonal Relationships with Friends, Parents, and Teachers When Using Facebook for Interaction. Creative Education, 04(05), 335-339. https://doi.org/10.4236/ce.2013.45049

Lott, A. J., \& Lott, B. E. (1965). Group cohesiveness as interpersonal attraction: A review of relationships with antecedent and consequent variables. Psychological Bulletin, Vol. 64, pp. 259-309. https://doi.org/10.1037/h0022386

McCroskey, J. C., \& McCain, T. A. (1974). The measurement of interpersonal attraction. Speech Monographs, 41(3), 261-266. https://doi.org/10.1080/03637757409375845

McGinley, H., \& Reiner, M. (1979). Contingency awareness and interpersonal attraction. Bulletin of the Psychonomic Society, 13(3), 175-178. https://doi.org/10.3758/BF03335052

Montoya, R. M., \& Horton, R. S. (2004). On the Importance of Cognitive Evaluation as a Determinant of Interpersonal Attraction. Journal of Personality and Social Psychology, 86(5), 696-712. https://doi.org/10.1037/0022-3514.86.5.696

Montoya, R. M., \& Horton, R. S. (2014). A Two-Dimensional Model for the Study of Interpersonal Attraction. Personality and Social Psychology Review, 18(1), 59-86. https://doi.org/10.1177/1088868313501887

Nikoleizig, L., Nestler, S., Krause, S., Moore, D., \& Biesanz, J. (2019). Prediction of Group Performance: The Interplay of Individual Performance, Interpersonal Attraction, and Interpersonal Behavior. Collabra: Psychology, 5(1), 1-14. https://doi.org/10.1525/collabra.220

Pellegrini, A. (2007). Is aggression adaptative? Yes: Some kinds are and in some ways. Aggression and Adaptation: The Bright Side to Bad Behavior, 85-105.

Rosenberg, M. J., Hovland, C. I., McGuire, W. J., Abelson, R. P., \& Brehm, J. W. (1960). Attitude organization and change: An analysis of consistency among attitude components. (Yales studies in attitude and communication.), Vol. III. In Attitude organization and change: An analysis of consistency among attitude components. (Yales studies in attitude and communication.), Vol. III. Oxford, England: Yale Univer. Press.

Ryckman, R. M., Robbins, M. A., Kaczor, L. M., \& Gold, J. A. (1989). Male and Female Raters' Stereotyping of Male and Female Physiques. Personality and Social Psychology Bulletin, 15(2), 244-251. https://doi.org/10.1177/0146167289152011

Sabatelli, R. M., \& Rubin, M. (1986). Nonverbal expressiveness and physical attractiveness as mediators of interpersonal perceptions. Journal of Nonverbal Behavior, 10(2), 120-133. https://doi.org/10.1007/BF01000008

Sharma, A., \& Gautam, J. (2013). Personality, Subjective Well-Being and Interpersonal Attraction in Adolescents. Indian Journal of Positive Psychology, 4(1), 205.

Suler, J. (2004). The Online Disinhibition Effect. CyberPsychology \& Behavior, 7(3), 321-326. https://doi.org/10.1089/1094931041291295

Ünal-Çolak, F., \& Kobak, K. (2011). Determining Interpersonal Attraction in Educational Environment. International Journal on New Trends in Education and Their Implications, 2(1), 47-56.

Walster, E., Berscheid, E., \& Walster, E. H. (1978). Equity theory and attraction. Interpersonal Attraction, 125-146. 